a cross-over design consisted of two 21-day adaptation periods followed by a $2 \times 4$-day balance period with faeces- and urine-sampling. The nutrient- and mineral content in the dry matter of the bald quality hay (A) was : 86.3 p. 100 organic matter (OM), 31.5 p. 100 crude fibre (CF), 12.3 p. 100 crude protein (CP), 0.51 p. $100 \mathrm{Ca}, 0.35$ p. 100 P, 0.16 p. $100 \mathrm{Mg}$, 2.58 p. $100 \mathrm{~K}, 0.03$ p. $100 \mathrm{Na}$ and $4.69 \mathrm{MJ} / \mathrm{kg}$ net energy lactation (NEL) that of the good quality hay (B) was : 89.4 p. $100 \mathrm{OM}, 25.7$ p. $100 \mathrm{CF}, 14.6$ p. $100 \mathrm{CP}, 0.70$ p. $100 \mathrm{Ca}$, 0.36 p. $100 \mathrm{P}, 0.18$ p. $100 \mathrm{Mg}, 3.05$ p. $100 \mathrm{~K}, 0.03$ p. $100 \mathrm{Na}$ and $5.45 \mathrm{MJ} / \mathrm{kg} \mathrm{NEL}$.

Feeding of the bad quality hay led - compared to the good quality - one to a significantly $(\mathrm{P}<5$ p. 100$)$ reduced level of feed intake $(\mathrm{A}: 1.1 \mathrm{~kg} \mathrm{DM} /$ day $; \mathrm{B}: 1.9 \mathrm{~kg} \mathrm{DM} /$ day $)$ followed by a striking decline in the milk production (A: $1.0 \mathrm{~kg} /$ day; $\mathrm{B}: 1.9 \mathrm{~kg} / \mathrm{day}$ ). Furthermore, digestibility of OM (A : 63.9 p. $100: \mathrm{B}: 70.2$ p. 100) and of CF (A : 68.3 p. $100 ; B: 71.2$ p. 100$)$ was significantly lower. No significant difference could be observed in CP (A: 63.7 p. 100 ; B : 64.6 p. 100).

Owing to homeostatic regulation mechanisms the animals which received diet $A$ were - in spite of the inadequate Ca- and P-supply - able to balance their $\mathrm{Ca}$ - and P-metabolism to a large extent. The daily Ca-turnover in $\mathrm{g}$ in groups $\mathrm{A}$ and $\mathrm{B}$ was respectively : intake $4.75,12.79$; faeces $3.80,11.13$; urine $0.01,0.08$; milk $1.17,2.03$ and retention - 0.24 resp. -0.47 . The corresponding figures for the P-turnover were intake 3.94, 6.95; faeces $2.32,4.83$; urine $0.48,0.10$; milk $0.90,1.48$ and retention 0.25 resp. 0.54 . In p. 100 of the intake there was a significant difference between the two groups for the urine Ca-excretion as well as for the faeces- and urine P-excretion.

The large $\mathrm{K}: \mathrm{Na}$ ratio of diet $\mathrm{B}(30: 1)$ did not lead to the partly described excessive Na-excretion in the urine. On the other hand a depressive influence of the relatively high K-supply on the Mg-digestibility was observed (A : 36.0 p. 100, B : 29.0 p. 100, P $<5$ p. 100).

Neither the relatively narrow correlation (as it is described by some authors) between the crude fibre content of the diet and the mineral utilization nor the positive influence of the crude protein content of the diet on the Ca-retention could be observed in this experiment. This partly results from the relatively small differences in the CF- and CP-content of the diet. The correlation between energy supply and P-retention was also only low ( $r=0.43$ ).

Key words : Roughage, quality, intake, nutrient, mineral utilization, goat.

\title{
Weight and metabolism of goat adipose tissues during pregnancy and lactation
}

\section{P. BAS *, P. MORAND-FEHR *, Annie ROUZEAU *, Y. CHILLIARD **}

\author{
*Station de Nutrition et Alimentation (I.N.R.A.) \\ Institut National Agronomique Paris-Grignon \\ 16, rue Claude-Bernard, 75231 Paris Cedex 05 (France) \\ $*$ Laboratoire des Productions Laitières (I.N.R.A.) \\ Theix, 63122 Ceyrat (France)
}

Variations in adipose tissue weight and metabolism during the reproductive cycle of goats were studied as the information in this field was scarce in high milk yielding ruminants.

Thirty one, 3-8 year old Alpine goats were slaughtered at five stages of the reproductive cycle : at $7(\mathrm{~W}-7)$ or 3 weeks $(\mathrm{W}-3)$ before parturition or respectively at 2 $(\mathrm{W}-2), 4(\mathrm{~W}+4)$ and between $36-39(\mathrm{~W}-36)$ weeks after kidding.

Maternal empty body weights were $50.7,51.2,47.0,47.9,47.8 \mathrm{~kg}$ with a coefficient of variation (C.V.) $23.4,18.8,9.1,13.0,9.5$ p. 100 respectively for animals slaughtered at $-7,-3,+2,+4,+36 \mathrm{~W}$. 
Internal fats were very developped at each stage, but subsutaneous adipose tissues were scarce and sternal (ST) tissue was the only dissectable subcutancous fat. Great omentum (GO) was always the heaviest. Its weight was 2750 (C.V. 42 p. 100), 2570 (C.V. 31 p. 100), 2540 (C.V. 81 p. 100), 2650 g (C.V. 40 p. 100) respectively for $W-7, W-3$, $w+3, w+4, w+36$ slaughtered goats. It represented about $45 \mathrm{p} .100$ of the internal fats. Perirenal (PR), mesenteric (MES), minus omentum (MO) and pericardic (PC) adipose tissues weights represented only about $25,20,4$ and $3 \mathrm{p}$. 100 of internal fats.

Sternal fat, by contrast was very low, about $150 \mathrm{~g}$ with a medium C.V. of $50 \mathrm{p} .100$ for each stage.

The correlation coefficients between the different adipose tissue weights were high $(\mathrm{r}>0.8)$ at $\mathrm{W}-7$ before parturition, then decreased around parturition for $\mathrm{W}-3$ and $W+2$ slaughtered goats and afterwards slowly increased up to 36 weeks of lactation. Two weeks after parturition, sternal weight semed to have a very weak correlation with others ( $r=0.33$ between $\mathrm{ST}$ and GO for $\mathrm{W}+2$ goats).

GO and PR tissues had a lower water content than the other adipose tissues. As for the other internal fats, water content rose after parturition. Its average value at the three stages : $\mathrm{W}+36, \mathrm{~W}-7$ and $\mathrm{W}-3$ were $5.5,5.1,8.9,12.0,7.9,22.5$ p. 100 respectively for GO, PR, MES, PC, MO and ST. But the average water content of these tissues at $\mathrm{W}+2$ and $W+4$ was respectively $12,10.1,19.6,13.6,8.5,14.3$ p. 100 .

Lipoprotein lipase activity expressed per $\mathrm{g}$ of wet tissue was higher in internal fat than in sternal tissue. Despite the low number of animals slaughtered at each stage and the wide variability between animals, it seemed clear that LPL activity was lower in late pregnancy. For great omentum, its activity was $61,13,78,18$ and $102 \mathrm{~nm} / \mathrm{mn}^{-1} / \mathrm{g}^{-1}$ (C.V. $=76,63,82,97$ and 83 p. 100) respectively for $W-7, W-3, W+2, W+4$, $\mathrm{W}+36$ slaughtered goats.

The variability between fat depot weights was wider than between stages of the reproductive cycle. Water and lipid contents which showed a water content variation between these stages seemed to be good indicators of lipolysis status particularly for great omentum and for perirenal adipose tissue. Minus omentum and sternal adipose tissue appeared to have a lower rate of lipolysis and lipogenesis than the others.

Key words : Goat, adipose tissue, pregnancy, lactation, lipoprotein lipase, fat content.

\title{
Selenium - Vitamin E in the nutrition of the Saanen kid
}

\author{
J. KESSLER, D. GUBLER, M. WANNER
}

Swiss Federal Research Station for Animal Production

Grangeneuve, $\mathrm{CH}-1725$ Posieux

Kids are dependent on an adequate intra- and extrauterine selenium supply, like livestock in general. Reduced growth and degeneration of the heart- and skeletal muscle (white muscle disease) are the main symptoms of an inadequate selenium - vitamin E supply.

By means of a single intramuscular injection of $5 \mathrm{ml}$ Injacom E-selenium (1) in the dam four weeks before the expected parturition time and/or by treating the young animal with $2 \mathrm{ml}$ Injacom E-selenium at the end of the 2 nd week of life the often insufficient supply in the kids with these micronutrients can be improved. This is shown by the development of the Seand vitamin E-content of the blood and by the activity of the Se-dependent GlutathionePeroxidase (GSH-Px) in the erythrocytes. At the age of 3, 4, 6, 8 and 10 weeks the measured

(1) Injacom E-selenium (Hoffmann-La Roche \& Co.) : Hydrous solution with $150 \mathrm{mg}$ vitamin E-acetate and $1.67 \mathrm{mg}$ sodium selenite-pentahydrate per $\mathrm{ml}$. 